\title{
Pemodelan Erosi dan Sedimentasi di DAS Bajulmati : Aplikasi Soil dan Water Assesment Tool (SWAT)
}

\author{
Mohamad Wawan Sujarwo, Indarto Indarto, dan Marga Mandala
}

Program Studi Pengelolaan Sumberdaya Air Pertanian, Pasca Sarjana, Universitas Jember; e-mail: indarto.ftp@unej.ac.id

\begin{abstract}
ABSTRAK
DAS bajulmati merupakan DAS kecil ( $\pm 173.4 \mathrm{~km} 2)$ yang berada di wilayah timur pulau Jawa. DAS bajulmati memiliki iklim yang spesifik yaitu relatif kering dengan musim kemarau yang panjang (8-9 bulan selama setahun). Meskipun kondisi iklim yang kurang mendukung, sebagian besar masyarakat bekerja sebagai petani landang. Adanya perluasan lahan pertanian non irigasi/ladang mengakibatkan tutupan vegetasi semakin berkurang. Oleh karena itu, evaluasi DAS bajulmati diperlukan untuk mengetahui dampak perluasan lahan pertanian terhadap laju aliran dan sedimentasi dengan kondisi iklim yang cukup spesifik (kering). Salah satu model evaluasi pengelolaan DAS terhadap perubahan lahan adalah model SWAT (Soil and Water Assessment Tool). SWAT dapat menggambarkan proses hidrologi (erosi dan sedimentasi) unit lahan. data DEM resolusi $(10 \times 10 \mathrm{~m})$ sebagai masukan utama untuk proses delinasi DAS. Data tanah, tutupan lahan, dan kontur digunakan untuk menentukan unit lahan/hydrolocal response unit (HRU) DAS. Data curah hujan dan iklim (suhu, kelembaban rata-rata, intensitas matahari, kecepatan angin) diperoleh dari stasiun yang tersebar di wilayah DAS. Semua data diintegrasikan ke dalam SWAT untuk menghitung proses hidrologi, erosi dan sedimentasi. Debit yang diamati digunakan untuk mengkalibrasi keluaran debit hasil SWAT di outlet DAS. Hasil kalibrasi debit menunjukkan nilai Nash-Sutcliffe Efficiency sebesar 0,53 dan validasi sebesar 0,5 serta koefisien determinasi sebesar 0,58 dan 0,78 (memuaskan) dan model dapat digunakan untuk ilustrasi proses hidrologi dalam DAS bajulmati. Analisis tingkat erosi SWAT menunjukkan bahwa 34,46; 39,19; dan 17,83 menunjukkan tingkat erosi sangat ringan sampai kategori sedang. Oleh karena itu, DAS Bajulmati masih dalam kategori aman karena rata-rata erosi berat dan sangat berat dibawah 10\%. Nilai sedimentasi tertinggi pada HRU 512 dan SubDAS 23 . Wilayah tersebut merupakan wilayah perkebunan dengan tingkat kemiringan diatas $40 \%$.
\end{abstract}

Kata kunci: Erosi, Sedimentasi, SWAT, Model, Hidrologi, Bajulmati

\begin{abstract}
Bajulmati is a small watershed $( \pm 173.4 \mathrm{~km} 2)$ in the eastern part of East Java. The watershed has a specific dry tropical climate. The dry season span from 8 to 9 month during a year. The expansion of non-irrigated agricultural land in the upland areas of this watershed reduce natural vegetation cover (forest area). This study aims to simulate the impact of agricultural land expansion on the flow and sedimentation. The SWAT model is used to simulate hydrological processes on the watershed. The Digital Elevation Model (DEM) clip form the DEMNAS use as main input to determine river network and watershed boundary. Soil, land cover and contour map used to determine the HRU (hydrological response unit) of he watershed. Rainfall and climate data (temperature, average humidity, solar intensity, wind speed) are obtained from nearest stations. All data then integrated into SWAT to calculate the discharge, erosion and sedimentation processes. Observed discharge data use for calibration and validation processes. The simulation interpreted by Nash-Sutcliffe Efficiency (NSE) and coefficient of determination (r2). Calibration period calculate the NSE and R2 $=0.53$ and 0.58 , while in validation NSE $=0.5$ and $\mathrm{R} 2=0.78$. Furthermore, erosion modelling show that most of zones classified as very mild to moderate erosion reta. Only less than $10 \%$ of the areas classified as heavy and very-heavy erosion rate. The highest sedimentation show in HRU 512 and Sub-watershed 23. The area covered by plantation area on steppest terrain (slope $>=40 \%$ ).
\end{abstract}

Keywords: Erosion, Sedimentation, SWAT, Model, Hydrology, Bajulmati

Citation: Sujarwo, M. W., Indarto, I. dan Mandala, M. (2020). Pemodelan Erosi dan Sedimentasi di DAS Bajulmati : Aplikasi Soil \& Water Assesment Tool (SWAT), 18(2), 218-227, doi:10.14710/jil.18.2.218-227

\section{Pendahuluan}

Proyeksi laju pertumbuhan penduduk di Indonesia setiap tahun sekitar $0.62 \%$ (Badan Pusat Statistik, 2013). Seiring dengan bertambahnya penduduk, kebutuhan ekonomi masyarakat semakin meningkat. Secara tidak langsung pertumbuhan masyarakat mendorong manusia untuk melakukan ekploitasi alam untuk memenuhi kebutuhan hidup. Salah satu perhatian yang sering berdampak buruk bagi alam yaitu kegiatan pembukaan lahan pertanian secara intensif terutama di wilayah yang memiliki kerentanan tanah cukup tinggi terhadap erosi 
(Suyana dan Muliawati, 2014). Perubahan penggunaan lahan berdampak pada kondisi lingkungan yang terus menurun yang berindikasi pada kejadian erosi dan sedimentasi tanah serta peningkatan debit runoff pada saat musim hujan.

Erosi terjadi akibat energi kinetik hujan yang memecah butiran tanah dan terbawa oleh air limpasan dari hujan (Satriawan dan Fuady, 2014). Beberapa penyebab erosi digolongkan menjadi tiga yaitu faktor energi yang meliputi erosivitas, aliran permukaan, angin, relief, sudut dan panjang lereng, serta jarak teras; factor ketahanan yang meliputi erodibilitas, infiltrasi, dan pengolahan tanah; serta factor pelindung yang meliputi kepadatan penduduk, tanaman penutup, nilai kegunaan lahan dan pengolahan lahan (Banuwa, 2013). Dampak dari proses erosi akan menghasilkan sedimen. Sebagian sedimen akan sampai dan masuk ke dalam sungai, dan terbawa ke luar DAS, sementara sebagian lainnya akan mengendap di sepanjang lintasan aliran permukaan pada bagian bawah lereng. Sedimentasi memicu peningkatan tinggi muka air di aliran sungai sehingga pada saat terjadi hujan potensi terjadi banjir semakin tinggi (Arsyad, 2010).

Kegiatan pertanian di wilayah DAS bajulmati menjadi perhatian bagi pegiat lingkungan karena adanya perluasan areal pertanian terutama daerah DAS bagian hulu (upperland) dan tengah (Middle land). DAS yang berbatasan dengan dua kabupaten tersebut Sebagian besar berada di Kecamatan Wongsorejo banyuwangi serta Asembagus dan Banyuputih Situbondo. Kawasan Wongsorejo masuk dalam zona pengembangan kawasan pertanian tanaman pangan dengan topografi wilayah pegunungan, perbukitan, dan daerah landai (Kementrian Pertanian, 2015). Kecamatan Wongsorejo juga merupakan wilayah Potensi Tanah Longsor pada level menengah sampai tinggi dan zona rawan kekeringan (Dinas Lingkungan Hidup Provinsi Jawa Timur, 2016).

Bentuk DAS yang melebar serta luasan DAS yang relative kecil $\left(173,4 \mathrm{~km}^{2}\right)$ akan menghasilkan debit air sungai yang relatif cepat saat terjadi hujan (Indarto, Soesanto, dan Wahyuningsih, 2010). Area DAS Bajulmati relatif kecil dengan saluran utama sepanjang $19 \mathrm{~km}$, rasio beda tinggi wilayah di hulu dan hilir DAS bajulmati cukup siginifikan sehingga berdampak peningkatan kecepatan aliran terutama pada saat terjadi hujan (Sujarwo et al., 2019).

Disisi lain, iklim di wilayah DAS bajulmati relatif kering dengan kondisi bulan kering lebih panjang dibandingkan dengan wilayah sekitar DAS bajulmati yaitu sekitar 8 sampai 9 bulan (Indarto, Susanto and Huda, 2012). Kalkulasi kejadian hujan diwilayah tersebut sekitar 34-49 hari hujan per tahun (Indarto, 2013). Di wilayah hilir DAS juga dibangun waduk yang digunakan untuk mendukung distribusi air irigasi di wilayah hilir.

Fenomena tersebut menunjukkan bahwa DAS bajulmati memiliki keunikan pada kondisi fisik DAS, iklim serta masyarakat. Kondisi DAS tersebut dapat dikaji dengan menilai beberapa indikator yang dapat digunakan seperti laju erosi, sedimentasi, serta aliran di dalam DAS (Menteri Kehutanan Republik Indonesia, 2014). Salah satu cara dalam pengelolaan DAS dengan menerapkan suatu model untuk mengetahui seberapa besar potensi erosi, sedimentasi dan aliran.

Banyak model pengelolaan yang berkembang dalam memprediksi dampak pengolahan lahan terhadap kondisi hidrologi dengan memanfaatkan tekonologi SIG (sistem Informasi Geografis) seperti USLE, MUSLE, RUSLE, WEPP, CREAMS, dan SWAT (Arsyad, 2010).

Model USLE (Universal Soil Loss Equation) merupakan model yang dibangun untuk menganalisa dampak erosi di setiap lahan. Semakin berkembangnya ilmu pengetahuan, model ini berkembang dengan menjadi M (Modeified) - USLE dan R (revised) - USLE. Perubahan USLE menjadi MUSLE terletak pada nilai erosivitas hujan yang ditranformasikan berdasarkan rasio aliran permukaan terhadap besarnya curah hujan pada kejadian tersebut(Kinnell, 1998). Kemudian MUSLE dikembangkan lagi menjadi RUSLE oleh Renard et al. (1997), dimana faktor erosivitas hujan merupakan hasil perkalian dari energi hujan total dengan intensitas hujan maksimum selama 30 menit.

Model WEPP (Water Erosion Prediction Project) merupakan model yang dikembangkan untuk prediksi erosi berdasarkan cuaca stokastik, teori infiltrasi, hidrologi, sifat fisik tanah, ilmu tumbuhan, hidrolika, dan mekanika erosi. Kemampuan model ini dapat memperkirakan kehilangan tanah (erosi dan sedimentasi) yang terdistribusi spasial dan temporal dari di seluruh lereng bukit atau untuk setiap titik pada profil lereng dapat diperkirakan secara harian, bulanan, atau rata-rata tahunan (Flanagan et al., 1995). Model WEPP memiliki berbagai keunggulan dibanding model USLE maupun RUSLE yaitu model ini dapat memprediksi secara spasial erosi, sedimen, maupun aliran pemukaan disaat terjadi hujan (Kinnell, 2017).

Model CREAMS (Chemicals, Runoff, dan Erosion From Agricultural Management Systems) merupakan Model yang mensimulasikan gerakan polutan termasuk unsur-unsur seperti pupuk ( $\mathrm{N}$ dan $\mathrm{P}$ ), pestisida, dan sedimen. Efek dari berbagai praktik pertanian dapat dinilai dengan simulasi potensi kehilangan air, tanah, nutrisi tanaman, dan pestisida hasil limpasan lahan pertanian (Kinsel, 1980). Struktur model terdiri dari tiga komponen utama: hidrologi, erosi/sedimentasi, dan kimia. Komponen hidrologi memperkirakan volume dan laju limpasan, evapotranspirasi, kadar air tanah, dan perkolasi. Bagian erosi/sedimentasi dari model mempertimbangkan proses pelepasan tanah, transportasi, dan pengendapan. Bagian kimia dari model mempertimbangkan nutrisi dan pestisida. Pengangkutan bahan kimia terlarut dan sedimen dievaluasi. Interaksi antara tanaman dan bahan kimia dalam zona akar juga dipertimbangkan. Model ini 
dirancang untuk memerlukan parameter kalibrasi minimum dan dimaksudkan untuk digunakan sebagai perbandingan berbagai strategi pengelolaan dan penggunaan lahan. Skala spasial model ini dimaksudkan untuk menjadi ukuran bidang pertanian (EPA, 2002)

SWAT (Soil and Water Assesment Tool) merupakan model yang digunakan untuk memprediksi pengaruh penggunaan lahan terhadap debit, sedimen, bahan kimia pertanian yang masuk ke sungai atau badan air pada suatu DAS. Model ini merupakan perkembangan dari model sebelumnya yaitu CREAMS dan USLE. (Neitsch et al., 2011). Model semi-distribusi ini memiliki kemampuan untuk mensimulasikan dengan skala terkecil (Hydrolical Response Unit) dengan periode panjang dengan waktu yang singkat (Arsyad, 2010). Siklus hidrologi yang disimulasikan dalam SWAT menggunakan persamaan neraca air yaitu:

$$
S W t=S W o+\sum_{i-1}^{t}(R d a y-Q s u r f-E a-W s e e p-Q g w)
$$

SWt adalah kandungan air tanah akhir, SWo adalah kandungan tanah permulaan pada hari ke-1, $\mathrm{t}$ adalah waktu dalam skala harian, Rday adalah jumlah curah hujan pada hari ke-i, Qsurf adalah jumlah aliran permukaan pada hari ke-i, Ea adalah evapotranspirasi pada hari ke-i, Wseep adalah jumlah air yang masuk dalam zona aquifer tanah pada hari ke-i, dan Qgw adalah aliran kembali (return flow) (Jain, Tyagi and Singh, 2010).

Pendugaan erosi dan sedimen pada model SWAT diprediksi pada tingkat HRU (Hydrolical Response Unit) menggunakan pendekatan MUSLE. Konsep SWAT menggambarkan air hujan yang jatuh mengalir ke tanah dan jumlahnya melebihi laju inflitrasi, maka akan terjadi limpasan air permukaan yang dapat mengakibatkan terjadinya erosi dan sedimentasi (Swami and Kulkarni, 2016). SWAT menghitung laju limpasan puncak dengan metode rasional yang telah dimodifikasi. Faktor-faktor Kusle, Cusle, Pusle, LSusle, dan CFRG.

DAS yang memiliki kondisi tanah dengan permeabilitas tinggi sangat berpengaruh terhadap aliran lateral. Air yang terkumpul di atas lapisan impermeabel akan menjadi sumber air. SWAT menghitung perkolasi pada setiap lapisan profil tanah dan proses ini hanya terjadi ketika kadar air tanah lebih dari kapasitas lapangan (Neitsch et al., 2011)

Beberapa penelitian di berbagai negara yang dilakukan oleh Zettam et al., (2017) di Afrika, Nguyen and Nguyen, (2014) di Vietnam, dan Rahmad, Nurman, dan Wirda, (2017); Christanto et al., (2018) di Indonesia menunjukkan metode SWAT mampu mensimulasikan proses hidrologi dengan nilai NashSutcliffe Efficiency (NSE) > 0,5. Model tersebut diharapkan dapat menjadi salah satu pertimbangan dalam membuat perencanaan pengelolaan DAS dengan indikator erosi dan sedimentasi di DAS Bajulmati.

Tujuan penelitian ini adalah melakukan pengujian model dengan kalibrasi, validasi debit dan simulasi prediksi besaran erosi dan sedimentasi di DAS Bajulmati.

\section{Metodologi}

\subsection{Lokasi studi}

Penelitian ini dilakukan di DAS Bajulmati. Secara administasi berada di dua kabupaten yaitu besar Situbondo dan Banyuwangi (Gambar 1).

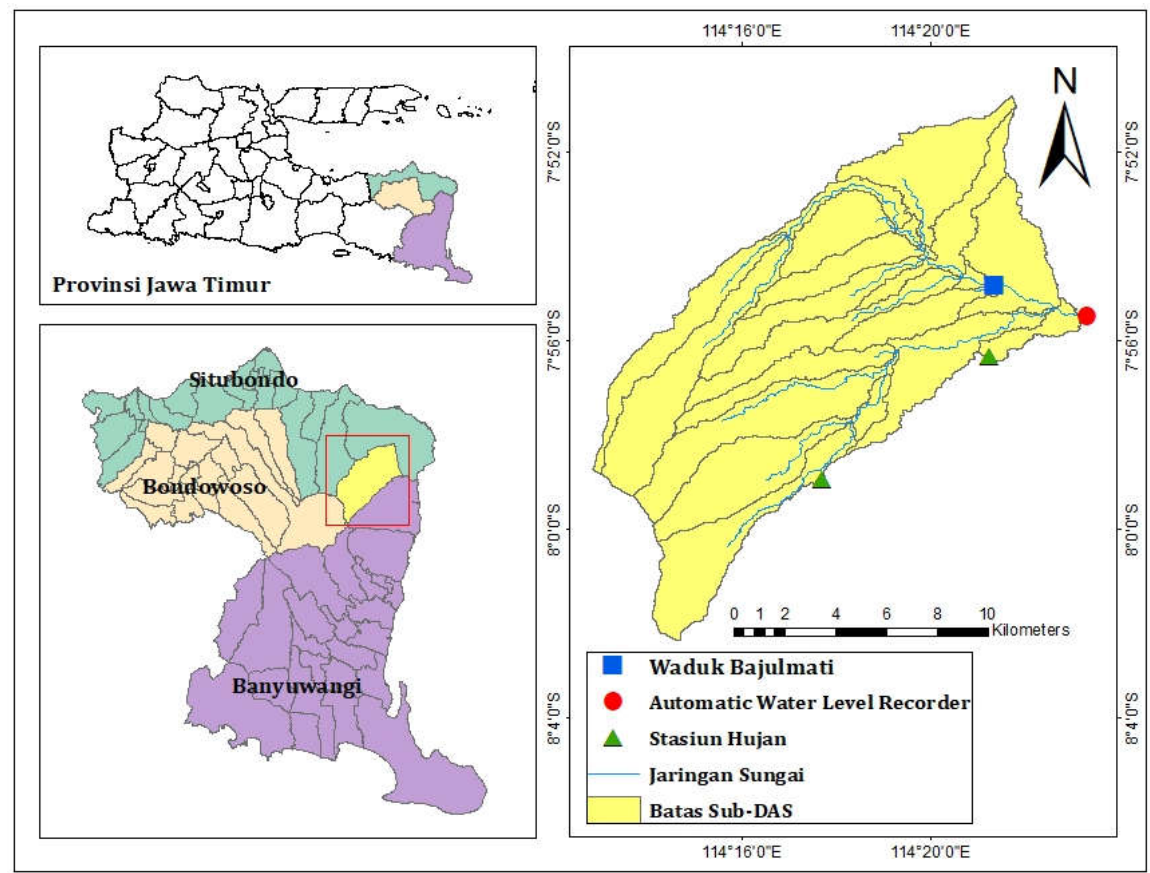

Gambar 1 Peta Wilayah Studi 


\subsection{Input Data}

Data masukan model berupa data spasial dan numerik. Masukan data spasial berupa data DEM (http://tides.big.go.id/DEMNAS/), tutupan lahan, tanah, dan kemiringan lereng(Kementrian Kehutanan, 2013). Data numerik berupa data ikim dan curah hujan harian (tabel 1). Data input diperoleh dari Balai Pengelolaan Daerah Aliran Sungai dan Hutan Lindung (BPDAS-HL) Brantas Sampean, UPT Pengelolaan Sumberdaya Air (PSDA) Pekalen Sampean, dan Badan Meteorologi, Klimaatologi, dan Geofisika (BMKG) Online.

Data iklim diperoleh dari BMKG online (http://dataonline.bmkg.go.id/) wilayah banyuwangi dan curah hujan diperoleh dari Pengelolaan Sumberdaya air Wilayah sungai Sampeyan Pekalen yang membawahi DAS bajulmati. Hasil debit simulasi dibandingkan dengan hasil debit pengukuran lapang dan dilanjutkan pada tahap kalibrasi.

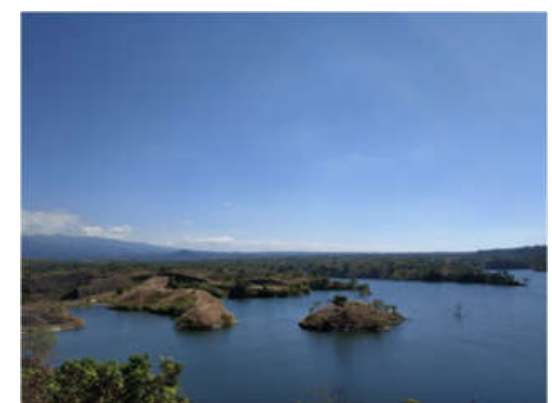

Gambar 2 Waduk Bajulmati

(sumber: hasil survey, 2019)

\subsection{Prosedur}

Proses menjalankan model dimulai dari deliniasi DAS, kemudian dilanjutkan porses Hydrological Response Unit (HRU) serta memasukkan data iklim yang telah diolah yaitu (curah hujan, suhu maksimum dan minimum, kelembaban rata-rata, kecepatan angin, dan radiasi matahari) dalam skala harian.

Tabel 1. Deskripsi masukan model

\begin{tabular}{ccc}
\hline \hline Tipe data & Sumber & keterangan \\
\hline $\begin{array}{c}\text { DEM (Digital elevation } \\
\text { model) }\end{array}$ & $\begin{array}{c}\text { Badan Informasi Geospasial Indonesia } \\
\text { http://tides.big.go.id/DEMNAS/Jawa.php } \\
\text { Lembaga Penelitian Tanah, 1998 Bogor, } \\
\text { Peta Tanah }\end{array}$ & $\begin{array}{c}\text { Indonesia } \\
\text { Tutupan lahan }\end{array}$ \\
Climate /meteorological & Directorate general of forestry & Scale 1:250.000 \\
Rainfall & Badan Meteorologi dan Klimatologi Geofisika & Bumi Indonesia 2001) Scale 1:250.000 \\
& Bajulmati, Maelang, Pasewaran stations. & 1995-2017 (22 years) \\
\hline
\end{tabular}

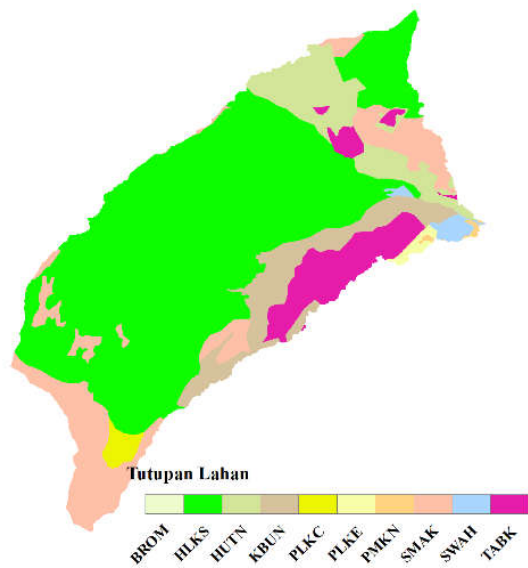

(a) Tutupan Lahan

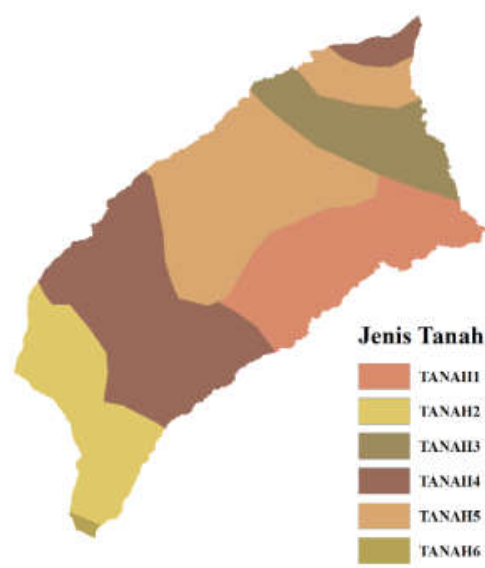

(b) Jenis Tanah

Gambar 3 Masukan Data Spasial Model

Keterangan: BROM (padang rumput), HLKS (hutan lahan kering sekunder), HUTN (hutan tanaman), KBUN (perkebunan), PLKC (pertanian lahan kering campuran), PLKE (pertanian lahan kering, PMKN (pemukiman), SMAK (semak belukar), SWAH (sawah irigasi), TABK (tanah terbuka), TANAH1 (aluvial, TANAH2 (andosol), TANAH3 (grumusol), TANAH4 (latosol), TANAH5 (mediteran), TANAH6 (regosol).

Setelah proses running SWAT, dilakukan pengujian model dengan proses kalibrasi dan validasi. Kalibrasi dan validasi bertujuan untuk mendapatkan hasil simulasi menyerupai kondisi Alamiah (Indarto, 2014). Langkah awal dalam melakukan proses kalibrasi dan kalibrasi adalah dengan mencari parameter sensitif disesuaikan dengan data lapang yang tersedia. Setelah parameter sensitif ditemukan, kalibrasi dan validasi dilakukan dengan cara membandingkan hasil simulasi dengan debit bulanan hasil observasi dengan analisis statistik sederhana yaitu mencari hubungan antara debit model dan debit terukur dengan koefisen determinasi $\left(\mathrm{R}^{2}\right)$ dan uji keandalan model dengana analisis Uji Nash-Sutcliffe 
Efficiency (NSE). Berikut merupakan tahapan dalam melakukan proses kalibrasi dan validasi.

1. Penentuan Parameter Sensitif Debit

Tahapan pertama pada saat melakukan kalibrasi dan validasi adalah mencari parameterparameter yang sensitif terhadap debit. Parameter sensitif didapatkan dari studi pustaka hasil penelitian terdahulu menggunakan model SWAT. Menurut Arnold et al. (2012), beberapa parameter yang sensitif terhadap perubahan limpasan permukaan (Surface runoff) seperti CN2, AWC, ESCO, EPCO, SURLAG, dan OV_N. Parameter yang sensitif terhadap perubahan terhadap aliran dasar (base flow) yaitu GW_ALPHA, GW_REVAP, GW_DELAY, GW_QWN, REVAPMN, RCHARG_DP. Menurut Wahdani (2011), terdapat 9 parameter yang harus disesuaikan secara manual untuk mendekati nilai debit sebenarnya yaitu meliputi Debit aliran (OV_N, CN2, SOL_AWC, SOL_K, GW_DELAY, ESCO, ALPHA_BF, CH_K2). Berdasarkan refrensi tersebut, parameter sensitif diuji coba dengan melakukan perubahan nilai parameter dan model dijalankan. Jika terjadi perubahan nilai debit dari keluaran model maka dilakukan uji ststistik sederhana meggunakan rumus persentase dengan memberi perlakuan perubahan nilai parameter sebesar $50 \%$ dari range nilai tiap parameter. Nilai parameter yang sensitif kemudian digunakan untuk proses optimasi nilai debit.

2. Optimasi Debit

Optimasi debit yaitu merubah nilai parameter sensitif agar hasil debit model mendekati nilai debit terukur. Pada tahap ini beberapa nilai parameter sensitif disesuaikan dengan kondisi alam di DAS Bajulmati seperti CN2 yaitu nilai kurva aliran tiap tutupan lahan, $\mathrm{CH}_{-} \mathrm{N} 2$ yaitu nilai manning pada saluran utama, SOL_AWC yaitu Kapasitas air tanah dan sebagainya. Kemudian dilanjutkan dengan mencari nilai terbaik pada parameter yang tidak dapat diamati secara langsung di alam dengan metode coba-coba (trial and error).

3. Uji Koefisien Determinasi $\left(\mathrm{R}^{2}\right)$

Uji koefisien determinasi bertujuan untuk melihat seberapa besar pengaruh antara debit terukur (observasi) dan debit model (simulasi) setelah dilakukan optimasi debit dengan merubah nilai parameter sensitif. Koefisien determinasi adalah nilai kuadrat dari koefisien korelasi berdasarkan Bravais-Pearson. Nilai $\mathrm{R}^{2}$ dapat dikalkulasikan menggunakan rumus:

Keterangan:

$$
\mathrm{R}^{2}=\frac{(X-\bar{X})^{2}-(X-Y)^{2}}{(X-\bar{X})^{2}}
$$

$X=$ Data observasi

$\bar{X}=$ Data observasi rata-rata

$Y=$ Data simulasi dari model.
Nilai $\mathrm{R}^{2}$ menghitung kecocokan data hasil perhitungan dengan hasil pengukuran lapang. Apabila nilainya semakin tinggi, maka mengindikasikan varian error yang rendah. Nilai $\mathrm{R}^{2}=0$ berarti tidak memiliki ikatan yang saling mempengaruhi antara satu dan lainnya, sedangkan jika $R^{2}=1$ berarti sebaran data prediksi sama dengan data observasi.

4. Uji Nash-Sutcliffe Efficiency (NSE)

Nash-Sutcliffe Efficiency (NSE) digunakan untuk menilai model dapat diterima atau tidak untuk mensimulasikan suatu kejadian hidrologi di suatu DAS. Penggunaan persamaan dari model efisiensi Nash-Sutcliffe Efficiency (NSE) adalah sebagai berikut:

$N S E=1-\left[\frac{\sum_{i=1}^{n}\left(Y_{i}^{o b s}-Y_{i}^{s i m}\right)^{2}}{\sum_{i=1}^{n}\left(Y_{i}^{o b s}-\bar{Y}^{o b s}\right)^{2}}\right]$

Keterangan:

$Y_{i}^{\text {obs }}=$ Data observasi ke-i,

$Y_{i}^{\text {sim }}=$ Data simulasi ke-i,

$\bar{Y}^{o b s}=$ Data observasi rata-rata,

$\mathrm{n}$ = Jumlah observasi.

Menurut Moriasi et al. (2007), Rentang nilai NSE terletak antara $-\infty$ sampai 1 , dengan NSE $=1$ merupakan nilai optimal. Nilai NSE antara 0,0 sampai 1,0 secara umum dilihat sebagai level performa model yang dapat diterima, sedangkan nilai NSE $\leq 0,0$ mengindikasikan bahwa rata-rata nilai data observasi merupakan alat prediksi yang lebih baik daripada nilai data simulasi, maka rentang nilai tersebut menunjukkan level performa yang tidak dapat diterima. Nilai efisiensi NSE dikelompokkan menjadi 4 kelas yang terdapat dalam Tabel 2.

Tabel 2. Kategori Nilai Efisiensi Model dengan NSE

\begin{tabular}{cc}
\hline \hline Nilai NSE & Kategori \\
\hline $0,75<\mathrm{NSE} \leq 1,00$ & Sangat Baik \\
$0,65<\mathrm{NSE}<0,75$ & Baik \\
$0,50 \leq \mathrm{NSE}<0,65$ & Memuaskan \\
NSE $<0,50$ & Tidak memuaskan \\
\hline
\end{tabular}

Sumber data Motovilov et al. (1999)

Setelah dilakukan kalibrasi kemudian masuk pada proses validasi model. Pada tahap ini model akan diuji untuk melihat konsistensi model. Validasi dilakukan dengan menjalankan model menggunakan parameter yang telah ditentukan selama proses kalibrasi dan membandingkan data debit yang sudah dikalibrasi dengan data pengukuran lapang pada periode lain. Metode statistik yang akan digunakan dalam melakukan validasi adalah model koefisien determinasi $\left(\mathrm{R}^{2}\right)$ dan model efisiensi Nash-Sutcliffe Efficiency (NSE) dengan kriteria yang sama seperti yang digunakan dalam proses kalibrasi. 


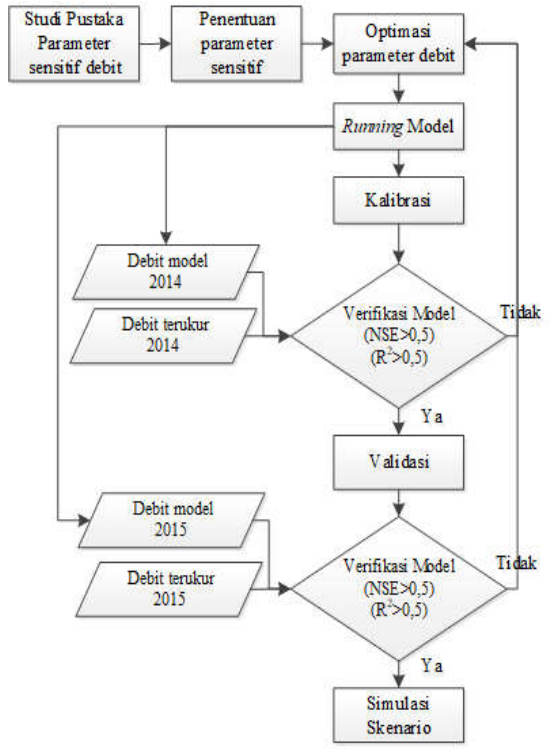

Gambar 4 Tahapan Kalibrasi dan Validasi Model SWAT

Prediksi Erosi dan Sedimentasi model dapat digunakan setelah simulasi model menunjukkan performa minimal dalam kategori memuaskan. Secara teknis, untuk melihat hasil erosi dan sedimentasi hasil model dapat mengakses keluaran berupa USLE dan SYLD. Nilai dalam bentuk numerik tersebut kemudian dimasukkan ke dalam data spasial HRU untuk mendapatkan gambaran secara spasial wilayah-wilayah yang memiliki potensi erosi mulai dari kategori sangat ringan sampai sangat berat.

Tabel 3. Kriteria Penilaian Indeks Erosi

\begin{tabular}{llllll}
\hline & \multicolumn{5}{c}{ Kelas Erosi } \\
\cline { 2 - 5 } $\begin{array}{l}\text { Solum } \\
\text { Tanah }\end{array}$ & I & II & III & IV & V \\
\cline { 2 - 5 }$(\mathrm{cm})$ & $<15$ & $15-60$ & $60-180$ & $180-$ & $>480$ \\
& & & 480 & \\
\hline Dalam & Sangat & Ringan & Sedang & Berat & $\begin{array}{c}\text { Sangat } \\
\text { Berat }\end{array}$ \\
$>90$ & Ringan & & & &
\end{tabular}

Dilanjutkan dengan mengkonversi data shape HRU menjadi data dalam bentuk grid untuk memudahkan kalsifikasi nilai erosi dan sedimentasi. Nilai model berupa nilai tahunan yang kemudian diklasifikasikan berdasarkan ketentuan tingkat bahaya erosi menurut (Kementrian Kehutanan, 2013). Kriteria klasifikasi erosi dapat dilihat pada Tabel 3 Kriteria Penilaian Indeks Erosi.

\section{Hasil dan Pembahasan}

\subsection{Penentuan Parameter Sensitif}

Hasil uji coba menunujukkan beberapa parameter sensitif yang dapat digunakan untuk optimasi nilai debit pada Tabel 4 .

Tabel 4. Parameter sensitif debit

\begin{tabular}{llc}
\hline \hline \multicolumn{1}{c}{ parameter } & \multicolumn{1}{c}{ Keterangan } & $\begin{array}{c}\text { Persentase } \\
\text { perubahan (\%) }\end{array}$ \\
\hline CN2 & Management & 3,61 \\
SOL_AWC & Soils & 3,52 \\
ESCO & HRU/Basin & 1,54 \\
GW_REVAP & Groundwater & 1,22 \\
REVAPMN & Groundwater & 0,11 \\
GWQMIN & Groundwater & 2,21 \\
\hline
\end{tabular}

Sumber data olah dari hasil uji presentase

Berdasarkan Tabel 4, Parameter yang sangat berpengaruh adalah perubahan nilia kurva aliran (CN), diikuti oleh perubahan parameter pada kapasitas simpan air tanah (SOL AWC) dan kedalaman ambang batas air akuifer (REVAPMN). parameter tersebut dilakukan optimasi debit dengan menyesuaikan kondisi alam di DAS Bajulmati.

\subsection{Optimasi parameter}

Terdapat 3 parameter yang digunakan untuk optimasi debit model yaitu CN,AWC, dan REVAPMN. Pemilihan 3 paramter disarkan pada nialai persentase perubahan yang dilakukan sebelumnya. Perubahan nilai CN ditunjukan pada Tabel 5 .

Tabel 5. Perubahan nilai CN Optimasi Debit

\begin{tabular}{ccccccccccc}
\hline $\begin{array}{c}\text { Tutupan } \\
\text { lahan }\end{array}$ & \multicolumn{2}{c}{$\begin{array}{c}\text { semak/padang } \\
\text { rumput }\end{array}$} & \multicolumn{2}{c}{ hutan } & \multicolumn{2}{c}{ kebun } & pemukiman & ladang/campuran & sawah \\
\hline tipe tanah & $\mathrm{d}$ & $\mathrm{b}$ & $\mathrm{d}$ & $\mathrm{b}$ & $\mathrm{d}$ & $\mathrm{b}$ & $\mathrm{D}$ & $\mathrm{D}$ & $\mathrm{b}$ & $\mathrm{b}$ \\
CN awal & 77 & 56 & 79 & 60 & 82 & 65 & 84 & 82 & 65 & 69 \\
CN akhir & 79 & 60 & 79 & 60 & 87 & 78 & 90 & 87 & 77 & 73 \\
\hline
\end{tabular}

Sumber data olah hasil trial and error parameter

CN2 merujuk pada jenis penggunaan lahan dan kelompok hidrologi tanah (Hydrology Soil Group). Proses kalibrasi debit pada parameter CN2 dilakukan dengan mengganti nilai $\mathrm{CN}$ sesuai dengan penggunaan lahan dan kelompok hidrologi tanah. Nilai debit model lebih kecil dibandingkan dengan nilai debit observasi, sehingga nilai $\mathrm{CN}$ harus dinaikkan dengan metode coba-coba dan disesuaikan dengan kondisi tutupan lahan di wilayah DAS Bajulmati.

Tabel 6. Perubahan nilai Avaliable Water Capacity Tanah

\begin{tabular}{cccccc}
\hline \hline Jenis tanah & Tanah 1 & Tanah 2 & Tanah 3 & Tanah 4 & Tanah 5 \\
\hline SOL_AWC awal & 0,11 & 0,11 & 0,162 & 0,12 & 0,41 \\
SOL_AWC akhir & 0,41 & 0,43 & 0,5 & 0,48 & 0,64 \\
\hline Sumber data olah hasil trial and error parameter
\end{tabular}

Demikian juga dengan nilai AWC (Avaliable Water Capacity) awal memiliki nilai rata-rata di bawah 0,5.
Penelitian yang dilakukan oleh Sasmito et al. (2017), menyimpulkan bahwa kadar lengas tanah 
mempengaruhi terhadap laju debit puncak. Semakin tinggi nilai kadar lengas tanah, maka nilai debit puncak semakin tinggi. Oleh karena itu, proses menaikkan debit aliran sungai DAS bajulmati dengan meningkatkan nilai AWC sampai pada kondisi optimum.

GWQMN merupakan kedalaman ambang batas air di akuifer dangkal. Aliran air tanah dapat menyumbang peningkatan debit aliran di permukaan. Aliran air tanah aka terjadi jika kedalaman air di akuifer dangkal (SHALLST) sama dengan atau lebih besar dari GWQMN (Arnold et al., 2012). Oleh karena itu untuk meningkatkan nilai debit, nilai GWQMIN diturunkan sebesar $500 \mathrm{~mm}$ dan menaikkan nilai SHALLST sebesar $2000 \mathrm{~mm}$ disesuikan dengan ketinggian sumur/aquifer dangkal.

\subsection{Uji Statistik}

Hasil proses deliniasi DAS menunjukkan titik outlet Automatic Water Level Recorder (AWLR)

berada pada sub-basin 14. Data observasi sedimen tidak tersedia di lapangan, sehingga kalibrasi menggunakan data debit. Penelitian yang dilakukan oleh Cheng et al. (2018), mengatakan bahwa sedimen dan beban polutan memiliki keterikatan kuat dengan debit DAS dan dapat digunakan untuk mengurangi ketidakpastian model aliran. Hasil model SWAT juga menunjukan keterikatan pengaruh sedimen dan debit sebesar $69 \%$.

Indikator optimasi debit adalah dengan mengkur tingkat akurasi model dengan menggunakan uji NashSutcliffe Efficiency (NSE) dan Koefisien Determinasi (R2). Data kalibrasi menggunakan data tahun 2000 dan validasi 2001 disesuaikan dengan kondisi tutupan lahan RBI dan sebelum dibangun waduk bajulmati agar merepresentasikan kondisi debit sebenarnya sebelum dibendung. Hasil optimasi debit menunjukkan nilai NSE dalam kategori memuaskan. Berikut grafik hasil optimasi debit pada Gambar 5 dan 6.

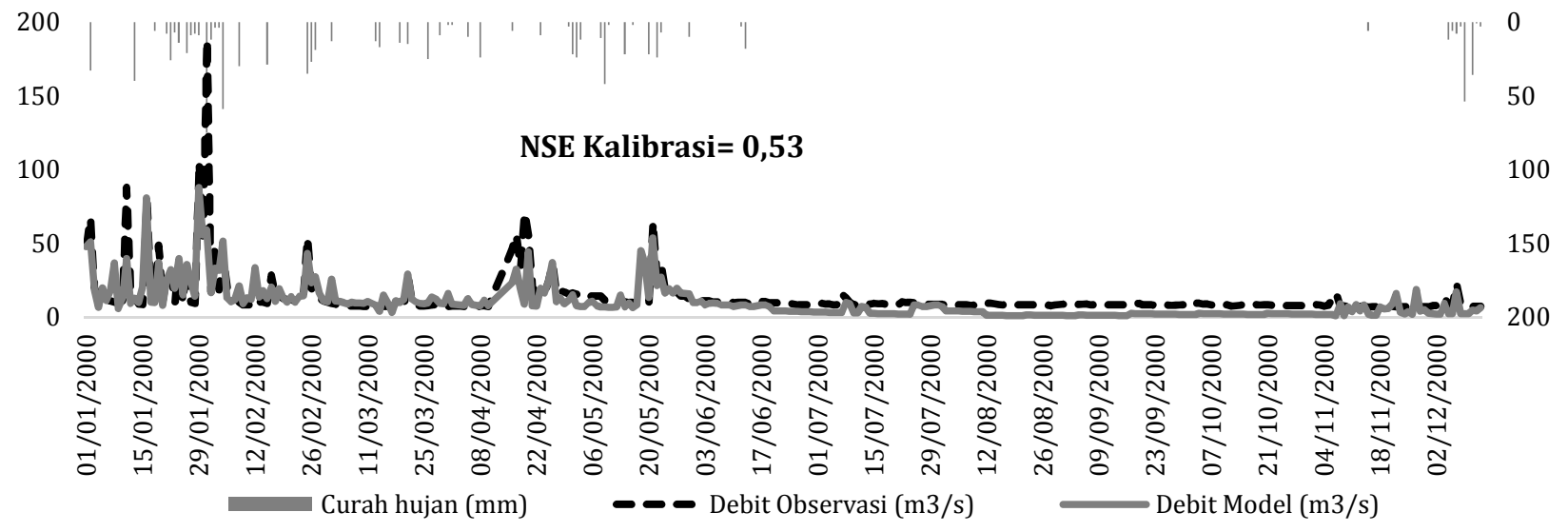

Gambar 5 Grafik perbandingan debit observasi dan debit kalirasi

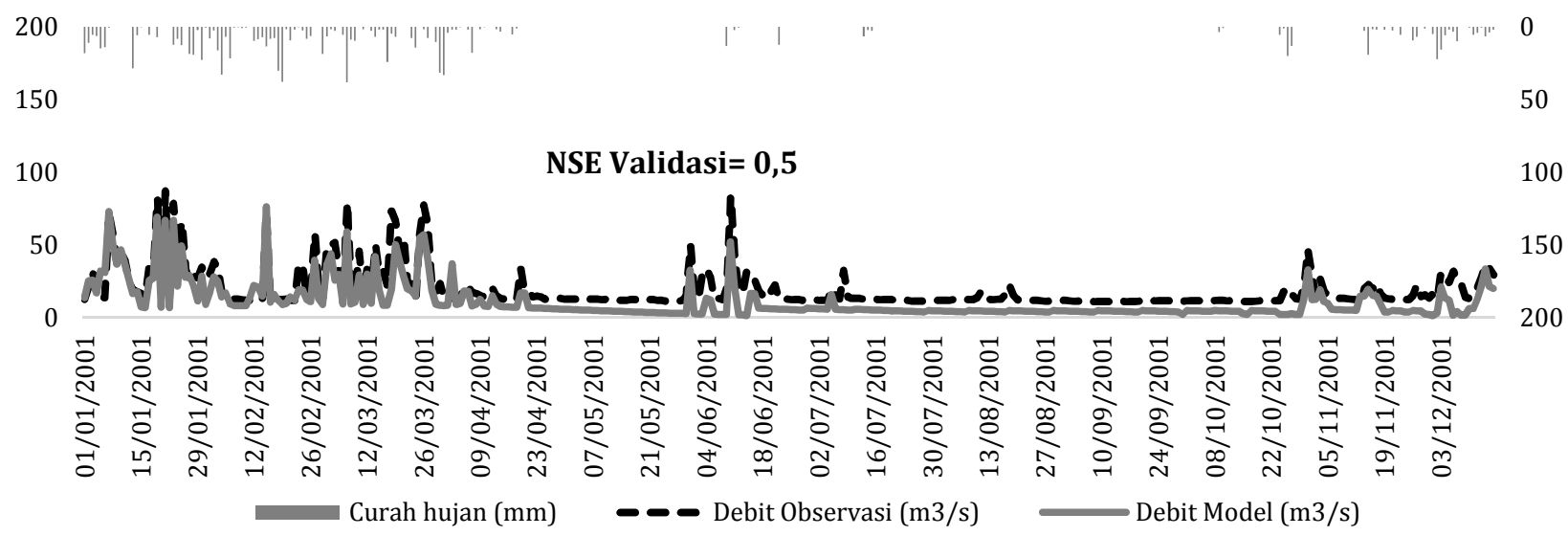

Gambar 6 Grafik perbandigan debit observasi dan debit validasi

Perbandingan debit antara observasi dan model masih menunjukkan debit model lebih rendah dibandingkan debit observasi. Pada saat proses kalibrasi, parameter diuji coba hingga mendapatkan nilai terbaik sampai tidak ada perubahan nilai debit. Uji Nash-Sutcliffe Efficiency (NSE) dan Koefisien Determinasi $\left(\mathrm{R}^{2}\right)$ digunakan untuk mengevaluasi 224 performa model. Evaluasi performa dilakukan dengan membandingkan debit observasi dengan debit simulasi model. Hasil uji performa menunjukkan bahwa hasil kalibrasi debit dengan perubahan nilai parameter sensitif dapat meningkatkan nilai NSE dari 0,19 menjadi 0,53 (memuaskan) pada Gambar 5. Hasil validasi menunjukkan penuruan nilai pada uji 
performa NSE yaitu sebesar 0,5 pada Gambar 6 . Demikian pula hasil uji $\mathrm{R}^{2}$ menunjukkan ada keterikatan data pada saat kalibasi tahun 2000 sebesar 0,58 dan meningkat pada tahap validasi sebesar 0,78 (Gambar 7).
Kalibrasi

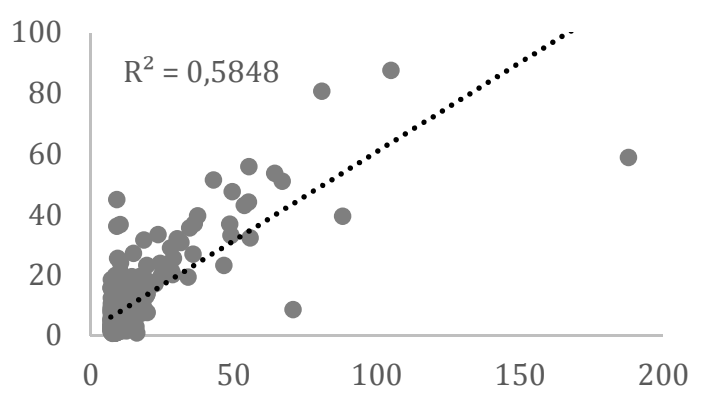

Validasi

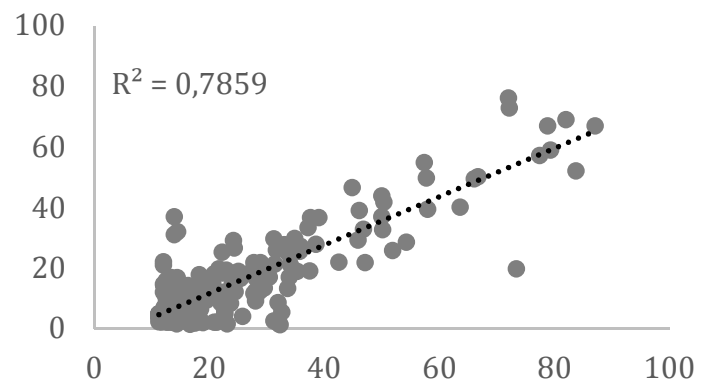

Gambar 7 Sebaran Data Debit Observasi Vs Model

\subsection{Erosi dan Sedimentasi}

Hasil delinasi DAS membentuk 23 sub-das yang tersebar di wilayah DAS bajulmati. erosi dan sedimentasi dinilai dengan menggunakan tutupan lahan 2017 yang didominasi oleh hutan lahan kering sekunder sebesar 51\% dari luas total DAS serta dikuti oleh semak belukar dan perkebunan sekitar $13 \%$ dan 10\%. Kemudian diikuti oleh tutupan lahan lainnya di bawah 10\%. Arsyad (2010), mengatakan bahwa erosi sangat dipengaruhi oleh jenis tutupan lahan. Semakin tinggi nilai faktor C (indeks pengeolaan tanaman), maka erosi yang dihasilkan akan semakin besar.

Sedimentasi pada unit lahan merupakan sedimentasi yang memiliki potensi masuk ke dalam aliran sungai dan tertampung di aliran di subdas. Hasil prediksi sedimentasi juga menunjukkan peningkatan. Selain akibat perubahan penggunaan lahan yang menyebabkan erosi, terjadinya sedimentasi juga dipengaruhi sifat fisik tanah. Tanah yang memiliki karakter halus dan tidak memiliki fraksi terhadap ikatan partikel yang satu dengan yang lainnya (Arsyad, 2010). Sebaran jenis tanah di wilayah DAS Bajulmati didominasi oleh tanah latosol, aluvial, dan mediteran yang masing-masing karakteristik tektur halus dan sedang. Kemampuan tanah untuk menahan erosi dinilai dari faktor erodibilitas tanah. Latosol memiliki tingkat erodibilitas sangat rendah, aluvial yaitu rendah, dan mediteran yang memiliki erodibilitas cukup tinggi.

Hasil prediksi model SWAT dengan menggunakan tutupan lahan tahun 2017 menunjukkan beberapa sub-das yang terindikasi mengalami erosi berat dan cukup berat yaitu sebagian wilayah sub-das 8,21,15,18 dan sebagian besar di subdas 11 dan 14 dengan kategori berat, selain itu sebagian wilayah hulu pada sub-das 20 dan 21 mengalami erosi yang sangat berat. Nilai erosi tertinggi juga dihasilkan di wilayah subdas 20 dan 22 . Hasil prediksi erosi model SWAT pada menunjukan nilai erosi tertinggi berada di unit lahan (HRU) 78 . Sebagian besar wilayah yang terdampak erosi berat dan sangat berat berada di kemiringan di atas 40\% dan lahan tersebut digunakan sebagai lahan petanian lahan kering (ladang). Sebaran tingkat bahaya erosi (TBE) yang dianalisa pada skala tahunan diilustrasikan pada Gambar 8.

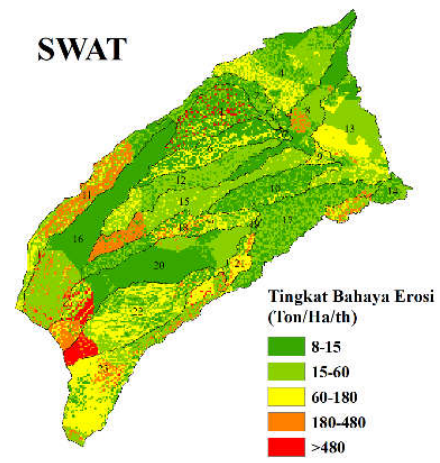

Gambar 8 Sebaran Erosi DAS Sanenrejo

Klasifikasi sebaran tingkat bahaya erosi kemudian dihitung luasan tiap kelas tingkat bahaya erosi tersebut. Tabel 7 menunjukkan bahwa sebagian besar kategori erosi dalam keadaan ringan dan sangat ringan yaitu sebesar 39,2 dan 34,5\%. Hasil prediksi erosi model SWAT menggambarkan bahwa DAS bajulmati berada dalam wilayah yang cukup aman terhadap laju erosi karena wilayah yang memiliki prediksi erosi berat dan sangat berat hanya 8,52\%.

Tabel 7. Luas Erosi Berdasarkan Tingkat Bahaya Erosi

\begin{tabular}{cccc}
\hline \hline Tingkat & \multicolumn{2}{c}{ SWAT } & \\
\cline { 2 - 3 } $\begin{array}{c}\text { Bahaya } \\
\text { Erosi }\end{array}$ & Luas (ha) & Persentase (\%) & Kategori \\
(Ton/ha/th) & & 34,46 & Sangat ringan \\
\hline $0-15$ & $5.981,7$ & 39,19 & Ringan \\
$15-60$ & $6.802,5$ & 17,83 & Sedang \\
$60-180$ & $3.095,5$ & 6,53 & Berat \\
$180-480$ & $1.132,8$ & 1,99 & Sangat berat \\
$>480$ & 346,1 & 100 & \\
\hline Luas total & $17.358,87$ & & \\
\hline
\end{tabular}

Sumber data olah hasil analisis GIS

Nilai sedimentasi tertinggi berada pada HRU 512 dan SubDAS 23. Keadaan wilayah pada HRU tersebut merupakan wilayah perkebunan dengan tingkat 
kemiringan diatas $40 \%$. luas wilayah HRU tersebut seluas 8 ha yaitu 0,05\% dari luas SubDAS 23 dan luas perairan yaitu $0,56 \%$ dari luas total perairan di DAS Bajulmati. Tingginya Nilai sedimentasi yang masuk pada perairan HRU tesebut merupakan pengaruh dari HRU sekitar yang sama-sama di dominasi oleh wilayah perkebunan. Wilayah perkebunan di DAS
Bajulmati sebagian besar adalah perkebunan kopi yang dikelola oleh perusahaan perkebunan dan rakyat. Oleh karena itu, upaya konsevasi dengan memberikan tanaman naungan sangat penting dilakukan demi menjaga lahan di wilayah DAS bajulmati tetap dalam kondisi sehat menurut (Menteri Kehutanan Republik Indonesia, 2014).

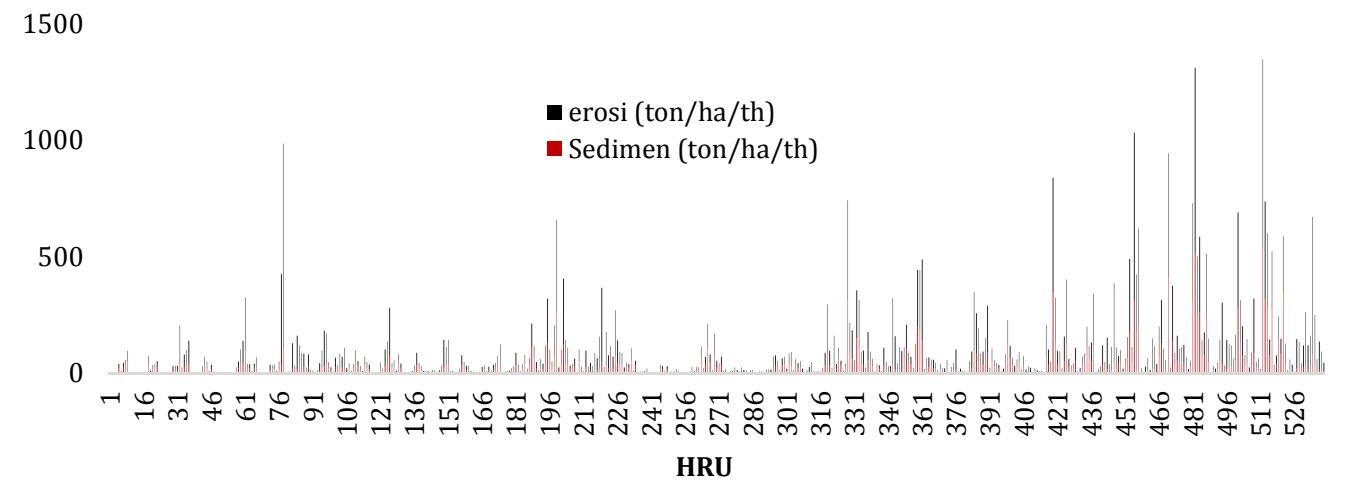

Gambar 9 Hasil Sedimen dan Erosi HRU

Gambar 9 Menunjukkan persebaran erosi dan sedimentasi yang tidak merata, jika diperhatikan pada gambar grafik, nilai laju erosi lebih besar dibandingkan dengan laju sedimentasi. Keadaan tersebut menandakan bahwa erosi yang terjadi di DAS bajumlati tidak semua menjadi sedimentasi. Sebagian besar erosi dan sedimentasi dengan kategori berat dan sangat berat berada di unit lahan (HRU) 324 sampai 528 yaitu pada sub-basin 14 sampai 23 .

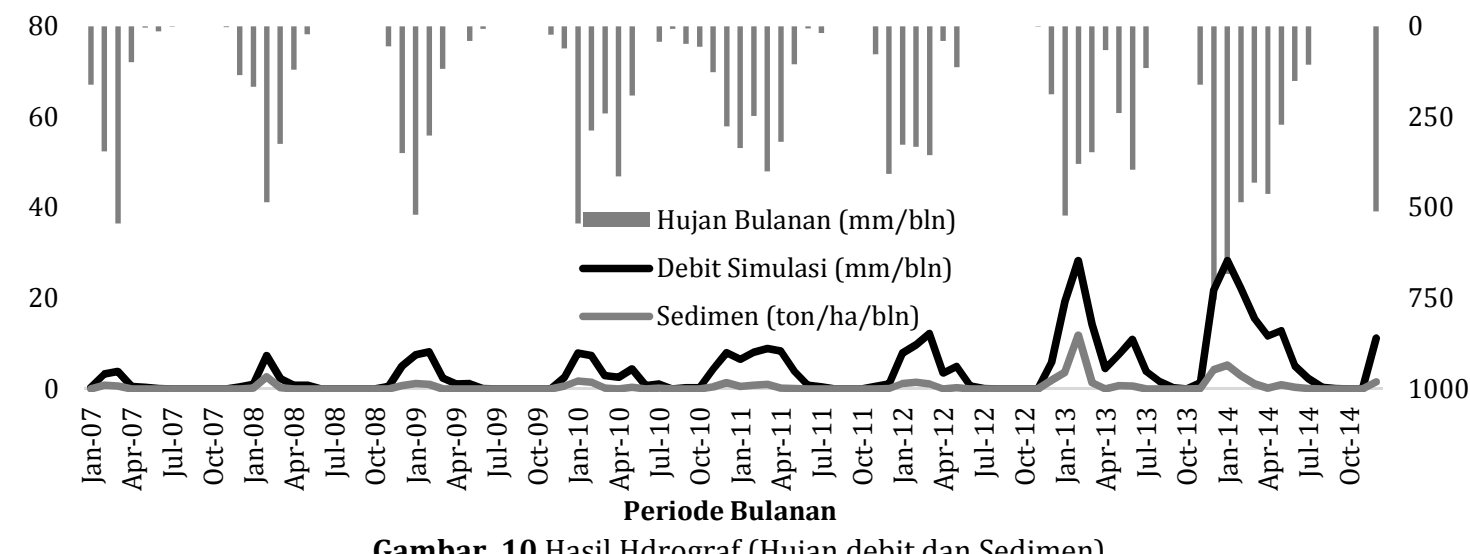

Gambar 10 Menunjukkan pola hidrograf yang seragam antara pola curah hujan, debit, dan sedimen. Peningkatan nilai intensitas hujan akan mempengaruhi terhadap nilai puncak debit yang semakin besar. Kenaikan nilai debit secara langsung akan membawa material tanah yang pada akhirnya menjadi sedimentasi di badan sungai. semakin tinggi debit maka erosi yang terbawa dan tersedimentasi juga semakin besar.

\section{Kesimpulan}

Hasil kalibrasi model SWAT menunjukkan bahwa performa dalam kategori memuaskan berdasarkan hasil uji Uji Nash-Sutcliffe Efficiency (NSE) mengalami peningkatan sebesar 34\% menjadi 0,53 dan validasi 0,5 serta hasil analisa koefisien determinasi menunjukkan keterikatan antara debit observasi dan model memiliki pengaruh di atas $50 \%$.
Hasil prediksi erosi dan sedimentasi menunjukkan bahwa DAS bajulmati sebagian besar masih dalam kondisi sangat ringan terhadap laju erosi.

\section{Ucapan Terima kasih}

Penelitian ini didanai oleh Hibah Keris Batch 1, LP2M - Universitas Jember, Tahun anggaran 2019 dengan Nomor Surat Penugasan 1430 /UN25.3.1/LT/2019 dan Nomor SK Rektor 6707/UN25/LT/2019 yang berjudul "Pemodelan Erosi, Sedimentasi, dan Aliran Permukaan Pada Level DAS Mikro - Aplikasi Swat dan Usle di DAS Bajulmati". Ucapan terimakasih disampaikan kepada BPDAS-HL (Bu Eka, Mas Hendra, Mas Galih, Bu Wahyu Widiastuti, dan Bu Meity), Pengelola Waduk Bajulmati, UPT PSDA Sampean-Baru dan semua pihak yang telah membantu dalam penyelesaian publikasi ini. 


\section{DAFTAR PUSTAKA}

Arnold, J. G. et al. 2012. Swat: Model Use, Calibration, and Validation. American Society of Agricultural and Biological Engineers, 55(4), pp. 1491-1508.

Arnold, J. G. et al. 2012. Soil Water Assessment Tool (SWAT) Input/Output Documentation Version 2012. Texas: Texas Water Resource Institute.

Arsyad, S. 2010. Konservasi Tanah dan Air. Bogor: IPB Press.

Badan Pusat Statistik. 2013. Proyeksi Penduduk Indonesia 2010-2035, Badan Pusat Statistik. Jakarta: Badan Pusat Statistik.

Banuwa, I. S. 2013. Erosi. Jakarta: Prenadamedia Group.

Cheng, Q. B. et al. 2018. The use of river flow discharge and sediment load for multi-objective calibration of SWAT based on the Bayesian inference. Water (Switzerland), 10(11), pp. 1-22. doi: 10.3390/w10111662.

Christanto, N. et al. 2018. Analisis Laju Sedimen DAS Serayu Hulu dengan Menggunakan Model SWAT. 32(1), pp. 50-58.

Dinas Lingkungan Hidup Provinsi Jawa Timur. 2016. Laporan Utama Informasi Kinerja Pengelolaan Lingkungan Hidup Provinsi Jawa Timur Tahun 2016. p. 597. doi: 10.1017/CB097811074 15324.004.

EPA. 2002. Chemicals, Runoff, And Erosion From Agricultural Management Systems - Creams.

Flanagan, D. C. et al. 1995. Overview of the WEPP erosion prediction model. (July), pp. 1-12.

Indarto. 2014. Hidrologi (Dasar Teori dan Contoh Aplikasi Model Hidrologi). Jember: Bumi Aksara.

Indarto, I. 2013. Variabilitas Spasial Hujan Harian Di Jawa Timur. Jurnal Teknik Sipil ITB, 20(2), pp. 107-120. doi: 10.5614/jts.2013.20.2.4.

Indarto, Soesanto, B. and Wahyuningsih, S. 2010 Karakteristik Fisik-Hidro-Klimatologi (8) Delapan Das di Wilayah Upt Psaws Sampean Baru. (February).

Indarto, Susanto, B. and Huda, H. 2012. Studi tentang karakteristik fisik dan frekuensi banjir pada 15 DAS di Jawa Timur. Seminar Ketahanan Pangan. Universitas Jendral Soedirman, p. 16.

Jain, S. K., Tyagi, J. and Singh, V. 2010. Simulation of Runoff and Sediment Yield for a Himalayan Watershed Using SWAT Model. Journal of Water Resource and Protection, 2(3), pp. 267-281. doi: 10.4236/jwarp.2010.23031.

Kementrian Kehutanan. 2013. Petunjuk Teknis Penyusunan Data Spasial Lahan Kritis. Indonesia.

Kementrian Pertanian. 2015. Peta Pengembangan Kawasan PAdi dan Kedelai Kabupaten Banyuwangi, Provinsi Jawa Timur. 1st edn. Jakarta: Sekertariat Jendreral Kementrian Pertanian.

Kinnell, P. I. A. 1998. of Soil Research. Australian Journal of Soil Research, Volume 36, pp. 395-409. doi: 10.1071/SR99114.

Kinnell, P. I. A. 2017. A comparison of the abilities of the USLE-M, RUSLE2 and WEPP to model event erosion from bare fallow areas. Science of the Total Environment. Elsevier B.V., 596-597, pp. 32-42. doi: 10.1016/j.scitotenv.2017.04.046.

Kinsel, W. G. 1980. CREAMS: A Field Scale Model for Chemicals, Runoff, and Erosion From Agricultural Management Systems', (26).
Menteri Kehutanan Republik Indonesia. 2014. Peraturan Menteri Kehutanan Republik Indonesia Nomor: P. 60 /Menhut-Ii/2014 Tentang Kriteria Penetapan Klasifikasi Daerah Aliran Sungai, Menteri Kehutanan Republik Indonesia. Indonesia.

Moriasi, D. N. et al. 2007. Model Evaluation Guidelines For Systematic Quantification Of Accuracy In Watershed Simulations. 50(3), pp. 885-900.

Motovilov, Y. G. et al. 1999. Validation of a distributed hydrological model against spatial observations. Agricultural and Forest Meteorology, 98-99, pp. 257277. doi: 10.1016/S0168-1923(99)00102-1.

Neitsch, S. . et al. 2011. Soil \& Water Assessment Tool Theoretical Documentation Version 2009. Texas Water Resources Institute. doi: 10.1016/j.scitotenv.2015.11.063.

Nguyen, B. N. and Nguyen, H. K. L. 2014. Basin resources management: simulating soil erosion risk by soil and water assessment tool (SWAT) in Ta Trach river watershed, central Vietnam. Journal of Vietnamese Enviroment, 6(2), pp. 165-170. doi: 10.13141/JVE.

Rahmad, R., Nurman, A. and Wirda, A. 2017. Integrasi Model SWAT dan SIG dalam Upaya Menekan Laju Erosi DAS Deli , Sumatera Utara. Majalah Geografi Indonesia, 31(1), pp. 46-55.

Renard et al., 1997. 1997. Predicting Soil Erosion by Water: A guide to Conservation Planning With the Revised Universal Soil LOss Equation (RUSLE). Washington DC: Department of Agriculture (USDA).

Sasmito, S. et al. 2017. Pengaruh Kondisi Awal Kelengasan Tanah Terhadap Debit Puncak Hidrograf Satuan. Jurnal Teknik Sipil, 13(3), p. 228. doi: 10.24002/jts.v13i3.879.

Satriawan, H. and Fuady, Z. 2014. Teknologi Konservasi Tanah dan Air. Yogyakarta: Deepublish.

Sujarwo, M. W. et al. 2019. Assessment of Morphometric and Hydrological Properties of Small Watersheds in East Java Regions. Teknik SIpil, 26(2), pp. 97-110. doi: 10.5614/jts.2019.26.2.2.

Suyana, J. and Muliawati, E. S. 2014. Analisis Kemampuan Lahan Pada Sistem Pertanian Di Sub-Das Serang Daerah Tangkapan Waduk Kedung Ombo (Analysis Of Land Capability On Farming System At Serang SubWatershed Kedung Ombo Reservoir Catchment Area). Ilmu Tanah dan Agroklimatologi, 11(2), pp. 137-147. doi: $10.7793 /$ jcoron.20.014.

Swami, V. A. and Kulkarni, S. S. 2016. Simulation of Runoff and Sediment Yield for a Kaneri Watershed Using SWAT Model. Journal of Geoscience and Environment Protection, 4(1), pp. 1-15. doi: 10.4236/gep.2016.41001.

Wahdani, D. K. 2011. Perkiraan Debit Sungai Dan Sedimentasi Dengan Model Mwswat Di Sub-DAS Citarum Hulu, Provinsi Jawa Barat. Institut Pertanian Bogor.

Zettam, A. et al. 2017. Modelling hydrology and sediment transport in a semi-arid and anthropized catchment using the swat model: The case of the Tafna River (Northwest Algeria). Water (Switzerland), 9(3). doi: 10.3390/w9030216. 